\title{
Effect of BI Rate and Profit Sharing Rate on Financing Income Mudharabah at PT. Bank Muamalat Indonesia 2011- 2015 Period
}

Deni Iskandar SE and Fitranty Adirestuty

Institut Agama Islam Darusalam Ciamis, Universitas Pendidikan Imdonesia

E-mail: deniiskandar007@gmail.com

\begin{abstract}
This study The purpose of this study is to find out how the BI Rate effects to the mudharabah financing income, and how the profit sharing rate effects mudharabah financing income, and how the BI Rate and profit sharing rate effect mudharabah financing income. This type of research is quantitative research, the method used in this study is associative research (relationship) supported by a document analysis approach, the place which is the object of research is PT Bank Muamalat Indonesia, the sample used is the monthly financial statements of PT Bank Muamalat Indonesia in 2011 period 2015 by using the purposive sampling method. The variables in this study there are two variables, namely the independent variable (free) and the dependent variable (bound), there are two independent variables, namely BI Rate (X1) and Profit Sharing (X2) while the dependent variable is Mudharabah Financing Income (Y). The type of data used is secondary data obtained from financial reports published by BI, OJK and through the official website of PT Bank Muamalat Indonesia. Data analysis method used is descriptive analysis and panel data regression model with a significance level of $5 \%$ or 0.05 , then to process data using the application Eviews 7. The results of the analysis show that partially the BI Rate and Profit Sharing Rate (TBH) have a positive and significant effect on Mudharabah Financing Income, as evidenced by the value of the BI Rate variable $0.0024<0.05$, and the prob value of the Rate of Profit Sharing 0, $0000<0.05$. Taken together the BI Rate and Profit Sharing variables have a significant influence on Mudharabah Financing Income, this is evidenced by the value of prob F statistic 0,000 which is smaller than 0.05. The variable BI Rate and Profit Sharing Level has a contribution to explain Mudharabah Financing Income of $83.3 \%$, while the remaining $16.7 \%$ $(100 \%-83.3 \%)$ is explained by other variables not examined or not included in this research model
\end{abstract}

Keywords :Mudharabah financing, BI Rate, and profit sharing

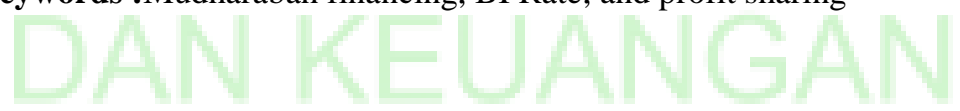

\section{INTRODUCTION}

Sharia Bank in Law No. 21 of 2008, Syari'ah Bank is a Bank that carries out its business activities based on shari'ah principles and according to its type consists of Sharia Commercial Banks and Syari'ah People's Financing Banks.

One of the functions of the establishment of Islamic banking is directing Muslims to carry out their Muamalah activities in an Islamic way, and avoiding the practice of usury and other practices that contain elements of gharar, in which these types of businesses are prohibited in Islam. (Huda \& Heykal, 2010: 39).

Therefore, the Shari'ah Bank comes with the principle of profit sharing and eliminates the interest system which in Islam is clearly forbidden, the principle of profit sharing in the Syari'ah Bank includes financing byagreement mudharabah and musyarakah, but which is often used in thecontract mudharabah.

Understanding in terms of mudaraba the contract of cooperation between shahibul maal (capital owner) and mudarib (who has the skills or expertise to manage a productive and lawful business). The results of the profit from the use of the funds are shared based on the agreed ratio, if there is a loss borne by Shahibul Maal (Huda \& Heykal, 2010: 72).

In fact, Syari'ah Bank has weaknesses, including customers who are not loyal to sharia banking, because they compare the percentage of profit sharing in the Sharia Bank with the interest rate in 
Conventional Banks. With a difference of around two percent (from the Conventional Bank interest rate), this customer segment is still loyal to the Syari'ah Bank. However, if more than that customers can move to Conventional Banks (Al-Arif, 2012: 120).

Another fact found in the research conducted by Suma, etc. (2011) turns out that the number of respondents who present the interest rate or profit sharing as a reference in choosing a Bank is almost balanced, as many as $41.88 \%$ of respondents said they chose the Bank based on high interest rates or profit sharing . The $43.83 \%$ of respondents stated that the interest rate or profit sharing is not their reason for selecting a Bank. The remaining $14.29 \%$ of respondents said they were hesitant. In this case indirectly prove that many Indonesian banking customers are rational by paying attention to the offer of interest rates and high profit sharing in Bank selection (Al-Arif, 2012: 121).

This is in line with what was expressed by Barno Sudarwanto as a practitioner in sharia financial institutions who said that when the BI Rate was raised it would affect sharia banking even though it did not affect directly, but the Shari'ah Bank was more focused on liquidity risk and credit or financing risk and the Shari'ah Bank must be careful in issuing financing. Then the Blincreased Rate to 7 percent affecting the sharia banking financing business. Because the cost of funds is expensive because there is a significant increase. Sharia banking is now cautious in channeling financing. ${ }^{1}$

Then in a study conducted by Widiyanto \& Diyani (2015), in his research entitled the analysis of the influence of BI interest rates onfinancing mudharabah, which shows that BI interest rates have a significant effect onfinancing mudharabah. Giannini (2013), in his research entitled factors influencingfinancing mudharabah in Sharia Commercial Banks in Indonesia, one of the factors influencingfinancing, mudharabah namely the rate of profit sharing, which proved to have a positive influence onfinancing mudharabah.

The following is a graph of the movement of the BI Rate, profit sharing andfinancing income mudharabah at PT Bank Muamalat Indonesia for the period 2011-2015.

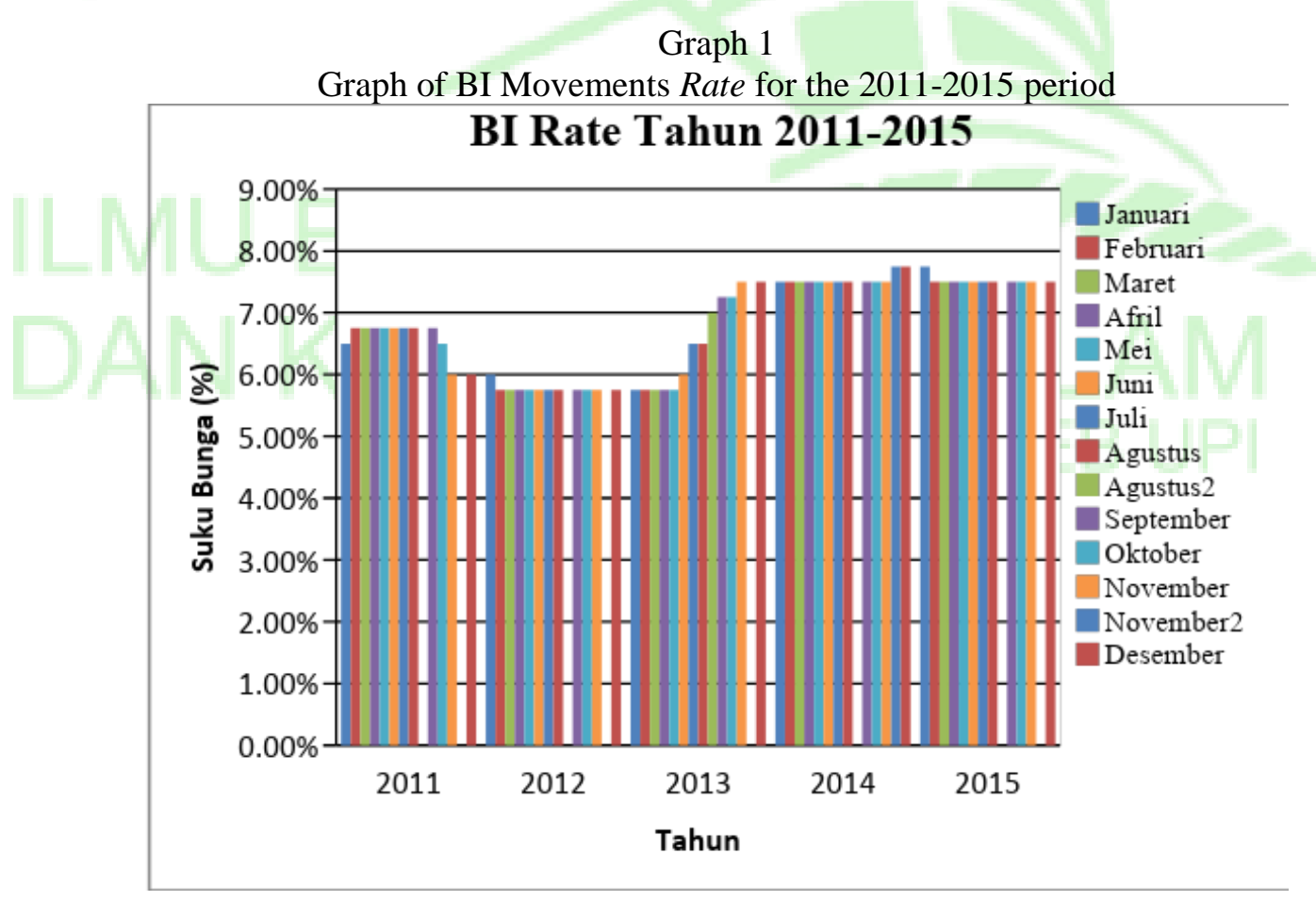

Based on graph 1.1 above shows that in February 2012 the BI Rate dropped to 5.75\%. This decision was taken as a further step to provide an impetus for Indonesia's economic growth amid the declining global economic performance, while still prioritizing the achievement of the inflation target and the

\footnotetext{
${ }^{1}$ http://www.republika.co.id/BI Rate Naik, Bank Syari'ah Hati-Hati Salurkan Pembiayaan _ Republika Online.htm
} 
stability of the Rupiah exchange rate. With this BIdecision Rate, the lower and upper corridor of Bank Indonesia monetary operations interest rate is $3.75 \%$ fordeposit facility rateand $6.75 \%$ for o / $\mathrm{n}$ loan facility (lending facility rate)

Then in November 2014 the BI Rate rose to $7.75 \%$, this increase was taken to anchor inflation expectations and ensure that inflationary pressures after the subsidized fuel price increase remained controlled, temporary, and could immediately return to the target track of $4 \pm 1 \%$ in the year 2015 . The policy is also consistent with progress in managing the current account deficit in a healthier direction. The widening of the monetary operation interest rate corridor is intended to maintain adequate liquidity and encourage financial market deepening.

Graph 2

Graph of Profit Sharing at

PT Bank Muamalat Indonesia for the period 2011-2015

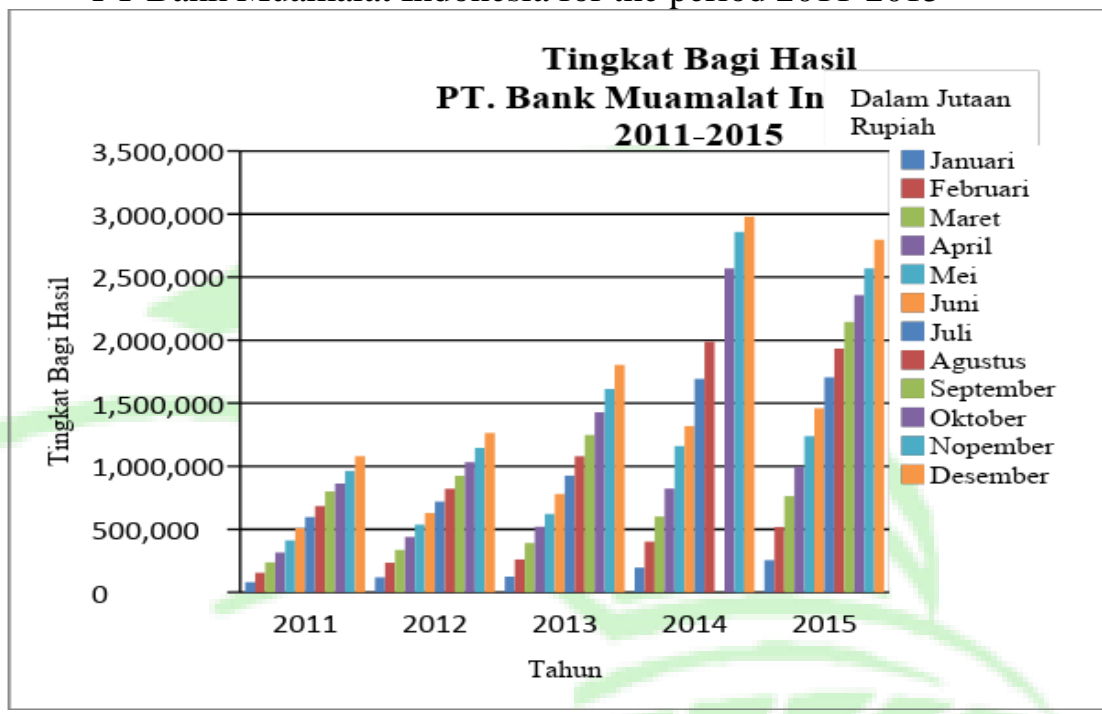

Growth in profit sharing rates at PT. Bank Muamalat Indonesia for the period 2011-2015 can be seen in graph 1.2 above shows that each year has increased and the highest profit sharing rate occurred in December 2014 although in 2015 it experienced a decrease but not significant.

\section{Graph 3}

Graph of Movement of Mudharabah Financing Income at

PT Bank Muamalat Indonesia for the period of 2011-2015

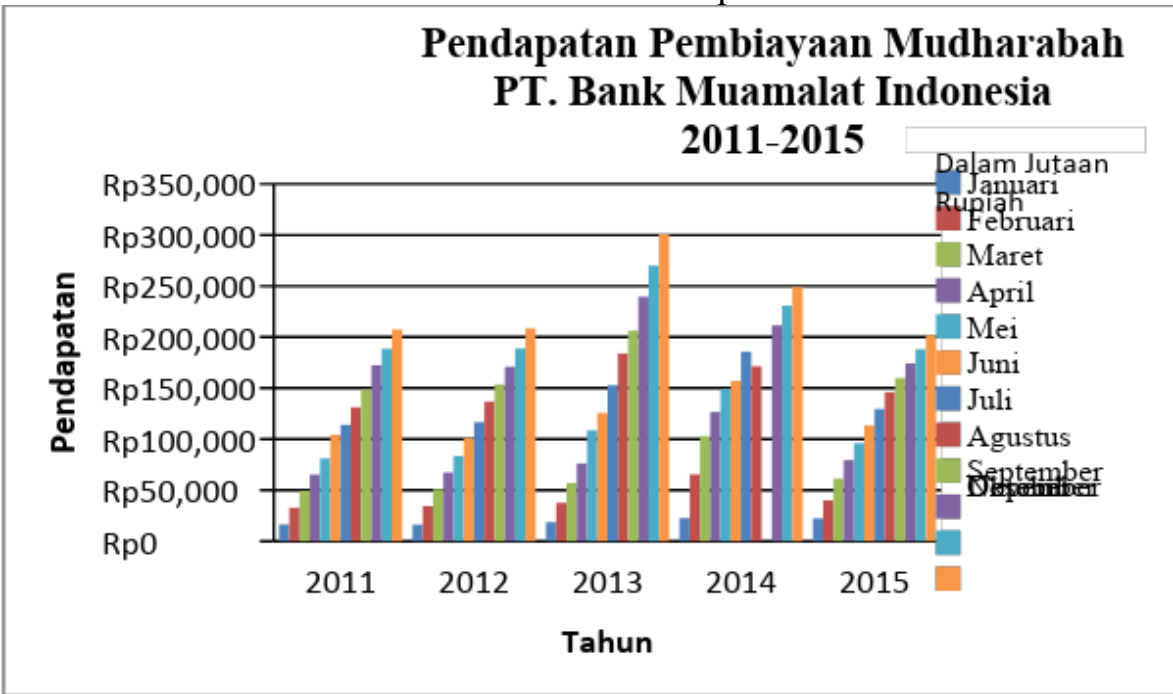


Based on graph 1.3 above the growth offinancing income of mudharabah PT. The highest Bank Muamalat occurred in December 2013 although the following year experienced a decline and the lowest occurred in January 2012.

By looking at the background above, the researchers took a case study on PT Bank Muamalat Indonesia with a focus on the financing problems in thecontract mudharabah. Bank Muamalat Indonesia is a bank that has proven to be not shaky at all with the monetary crisis that hit Indonesia in 1998. With an interest-free system is one of the flagship products of Bank Muamalat Indonesia that has brought the existence of sharia banking in Indonesia to the present.

Although Sharia banking does not use the interest system but uses a profit sharing system, the increase in the BI Rate will affect the Syari'ah Bank's financing income.

\subsection{Research Objectives}

1. To determine the effect of the BI Rate onfinancing income mudharabah at PT Bank Muamalat Indonesia.

2. To determine the effect of profit sharing onfinancing income mudharabah at PT Bank Muamalat Indonesia.

3. To determine the effect of the BI Rate and profit sharing rate onfinancing income mudharabah at PT Bank Muamalat Indonesia.

\subsection{Usefulness of Research}

The usefulness of research is as follows:

1. For Government

The results of this study are expected to be taken into consideration to take policy, especially policies relating to monetary activities. For the Bank, it is expected to provide indicators in channeling funds or financing.

2. For the Community

For this research community can be used as reading and guidelines in investing in the national banking industry sector and provide an overview and knowledge of the influence of the BI Rate and the rate of profit sharing onfinancing income mudharabah.

3. For Researchers

a. Increase researchers' insight both in terms of theory and practice regardingfinancing agreements mudharabah, BI Rate and profit sharing rates.

b. Understand more deeply about testing data processed with the application.

4. For the Academic World

For academics the results of this study are expected to be used as a reference or as a comparison material in the development for further research and for readers to gain insight into the BI Rate, the level of profit sharing andfinancing mudharabah.

\section{Literature Review}

\subsection{BI Rate The}

BI Rate is a policy interest rate that reflects theor stancestance monetary policyset by Bank Indonesia and announced to the public. BI Rate announced by the Board of Governors of Bank Indonesia each meeting of the Board of Governors of monthly and implemented on monetary operations conducted by Bank Indonesia through the management of liquidity (liquiditymanagement) in currency markets to achieve the operational target of monetary policy, the operational target of monetary policy is reflected in the development of interest rates on money market Interbank Overnight (interbank O / N). The movement in the interbank rate is expected to be followed by developments in deposit rates, and in turn bank lending rates. Taking into account other factors in the economy, Bank Indonesia will generally raise the BI Rate if future inflation is expected to exceed the set target, whereas Bank Indonesia will reduce the BI Rate if future inflation is expected to be below the set target. ${ }^{2}$

\footnotetext{
${ }^{2}$ http://www.bi.go.id/id/moneter/bi-Rate/penjelasan/Contents/Default.aspx
} 


\subsection{Profit Sharing}

In the view of Muhammad, "Profit sharing according to foreign terminology (English) is known as profit sharing. Profit in the economic dictionary means profit sharing. Profit sharing according to Indonesia's etymology is for profit"(Muhammad, 2002: 101).

According to Antonio (2011: 90), "Profit sharing is a system of funds processing in the Islamic economy, namely the division of business results between the owners of capital (shahibul maa /) and managers (mudharib)".

According to Karim, the result is a form of return (the acquisition of the change) of the investment contract, from time to time, it is uncertain and precarious. The size of the recovery depends on the results of the business that actually happened. Thus, it can be said that the profit sharing system is one of the shari'ah banking practices (Karim, 2004: 191).

In its application, the mechanism for calculating profit sharing can be done in two approaches, namely:

1) Approach (Profit SharingProfit Sharing)

Profit sharing according to Indonesia's etymology is for profit. In the economic dictionary is defined as profit sharing (Muhammad (2002: 101). Profit in terms is the difference that arises when the total income (total revenue) of a company is greater than the total cost (total cost).

In other terms profit sharingprofit sharing is the calculation ofbased on the net proceeds of total income after deducting the costs incurred to obtain the income, the shari'ah banking term often used is profit and loss sharing, where this can be interpreted as the division between profit and loss of income received on the results of operations that have been carried out.

2) approachrevenue Sharing(revenue),

revenue (income) in the dictionary economy is the result of money received by an enterprise from the sale of goods (goods) and services (services) that it generates from sales revenue (sales revenue)

In another sense revenue is a quantity that refers to the multiplication between the amount of out put resulting from production activities multiplied by the price of the goods or services of the production.

Calculation according to this approach is the calculation of profits based on income obtained from the fund manager, namely business income before deducting the business costs to obtain the income.

The principle of revenue sharing is applied based on the opinion of Shafi'i who said that mudharib should not use theproperty mudharabah as a cost either in a state of staying or traveling (on the road) because mudharib has a share of the profits so he is not entitled to get anything (income) from that property finally he will get a bigger part of shahibul maal. Meanwhile, for profit sharing is applied based on the opinion of Abu Hanifah, Malik, Zaidiyah who said that mudharib can spend theproperty mudharabah only if the trade is carried out, whether it is the cost of eating, drinking, clothing and so on. Hambali said that the mudharib may spend part of theproperty mudharabah either in a state of staying or traveling with the permission of shahibul maal, but the amount of income that may be used is a living that has been known (according to the habits) of the traders and not wasteful (Wiroso, 2005: 118).

a. Difference in Profit Sharing and Interest (Hak, 2011: 112).

Table 2.1

Differences in interest and profit sharing

\begin{tabular}{|l|l|}
\hline \multicolumn{1}{|c|}{ INTEREST } & \multicolumn{1}{c|}{ FOR RESULTS } \\
\hline $\begin{array}{l}\text { Determination of interest made at the time of the } \\
\text { contract with the assumption that it must always be } \\
\text { profitable. }\end{array}$ & $\begin{array}{l}\text { Determination of the ratio / profit sharing ratio made } \\
\text { at the time of the contract based on the possibility of } \\
\text { profit and loss. }\end{array}$ \\
\hline $\begin{array}{l}\text { The percentage is based on the amount of money } \\
\text { (capital) lent. }\end{array}$ & $\begin{array}{l}\text { The amount of the profit sharing ratio is based on the } \\
\text { amount of profit gained. }\end{array}$ \\
\hline $\begin{array}{l}\text { Fixed interest payments as promised without } \\
\text { consideration of whether the projects carried out } \\
\text { by the customer benefit or loss. }\end{array}$ & $\begin{array}{l}\text { Profit sharing depends on the benefits of the project } \\
\text { run if the business loses, the loss will be borne jointly } \\
\text { by both parties. }\end{array}$ \\
\hline
\end{tabular}


The amount of interest payments does not increase even though the number of profits is doubled or the state of the economy is "booming".

The existence of interest is doubtful (if not criticized) by all religions, including Islam.
The amount of profit sharing increases according to the increase in the amount of income.

No one doubts the validity of the profit sharing.

\subsection{Previous Research Previous}

research conducted by Badruzaman (2009), with the title analysis of the influence of third party funds, profit sharing rates, Bank Indonesia wadiah certificates on Syari'ah Bank financing in Indonesia (case study at PT Bank Syari'ah Mandiri), results This study shows that for the short and long term the profit sharing rate shows a significant effect on the amount offinancing mudharabah.

Andraeny (2011), his research entitled the analysis of the influence of third-party funds, profit sharing rates, and non-performing financing on the profit sharing-based financing volume in sharia banking in Indonesia, the results of his research showed that the level of profit sharing had a significant effect on the volume of profit-based financing in sharia banking in Indonesia.

Masduki (2012), with the title of the research namely the effect of the profit sharing ratio onfinancing volumes mudharabah and musyarakah (case study at PT Bank Syari'ah Mandiri 20092011), the results of his research show that the profit sharing ratio offinancing mudharabah has a positive and significant effect on financing volume mudaraba.

Giannini (2013), in his research entitled factors influencingfinancing mudharabah in Sharia Commercial Banks in Indonesia, one of the factors influencingfinancing, mudharabah namely the rate of profit sharing, which proved to have a positive influence onfinancing mudharabah.

Widiyanto \& Diyani (2015), in his research entitled analysis of the influence of BI interest rates onfinancing mudharabah, the results of his research show that BI interest rates have a significant effect onfinancing mudharabah.

Iyonu (2015), his research entitled the influence of the level of profit sharing onfinancing mudharabah (a case study of Sharia Commercial Banks in Indonesia), the results showed that the level of profit sharing affected the amount offinancing mudharabah. based on the estimation results obtained determination coefficient $\mathrm{R}^{2}$ of 0.978 or $97.8 \%$ were able to prove that the effect of the levelfinancingfor the results of of $97.8 \%$ and the remaining $2.2 \%$ came from unobserved variables such as the ratio of capital and the level of profit.

Fatmawati (2017), with the title of the study the influence of the BI Rate and the Bank's soundness on the profit sharing rate offinancing for the mudharabah Bank Syari'ah Mandiriperiod 2008-2015, the results of the research show that the BI Rate has a positive and significant effect on the level of profit sharing offinancing mudharabah.

\subsection{Thinking Framework}

Based on the theoretical basis and results of previous research and problems that have been raised, then as the basis for formulating a hypothesis The following is presented in the framework of thought outlined in the research model in the following figure:

Figure 1

Research Thinking Framework
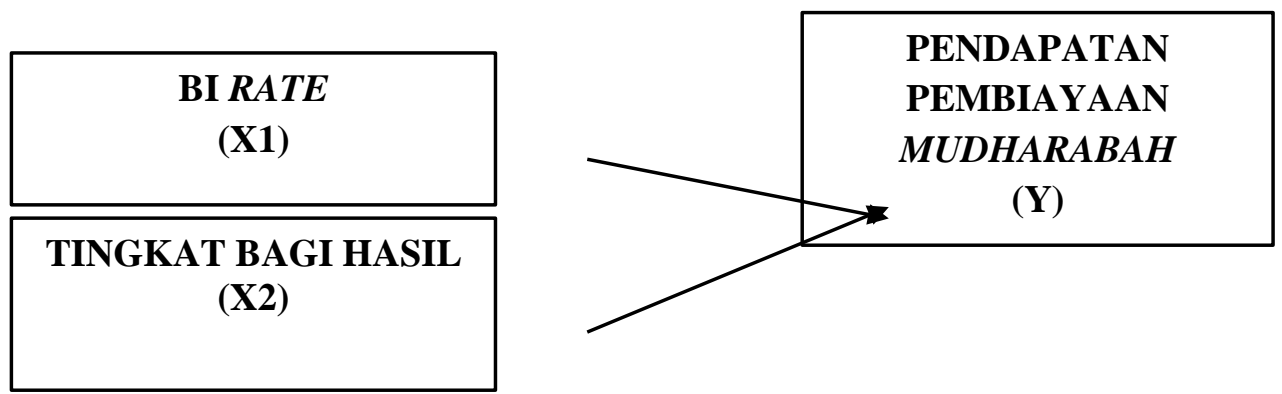


\subsection{Hypothesis}

Hypothesis is a conclusion or a temporary answer that still needs proof of the truth.

The hypothesis of this study is as follows:

$\mathrm{Ho}_{1}$ : The BI Rate does not affect thefinancing income mudharabah at PT. Bank Muamalat Indonesia.

$\mathrm{Ha}_{1} \quad$ : BI Rate affects thefinancing income mudharabah at PT. Bank Muamalat Indonesia.

$\mathrm{Ho}_{2}$ : The rate of profit sharing does not affect thefinancing income mudharabah at PT. Bank Muamalat Indonesia.

$\mathrm{Ha}_{2}$ : The rate of profit sharing affects thefinancing income mudharabah at PT. Bank Muamalat Indonesia.

$\mathrm{Ho}_{3} \quad$ : The BI Rate and profit sharing rate do not affect thefinancing income mudharabah at PT. Bank Muamalat Indonesia.

$\mathrm{Ha}_{3} \quad$ : BI Rate and profit sharing rate affectfinancing income mudharabah at PT. Bank Muamalat Indonesia.

\section{Research Methods}

\subsection{Types and Sources of Data The}

place that is the object of the research is PT Bank Muamalat Indonesia which was founded in 24 Rabius Tsani 1412 H or November 1, 1991, initiated by the Indonesian Ulema Council (MUI) and the Government of Indonesia, and began its operations on 27 Shawwal 1412 H or May 1, 1992. With real support from Indonesian Muslim Intellectual Association (ICMI) exponents and several Muslim businessmen. ${ }^{3}$ Chosen because it has a long history and is the first Syari'ah Bank in Indonesia and purely sharia.

\subsection{Population and Sample}

The population in the study here is PT. Bank Muamalat Indonesia, which is the first Syari'ah Bank in Indonesia which is purely shari'ah and proved to not falter in the monetary crisis that occurred in 1998. While the sample in this study is financing with a profit sharing scheme namely mudharabah which is a contract that is often used in every sharia banking in Indonesia especially PT. Bank Muamalat Indonesia.

\subsection{Data Methods and Analysis}

To estimate the model coefficients with panel data. The data panel modeling basically combines model formation which is formed based ontime seriesand based on cross section. Regression analysis is carried out to see the effect of the variable BI rate and profit sharing rate onfinancing income mudharabah at PT. Bank Muammalat Indonesia for the period of 2011-2015. So in this study, regression analysis was carried out using analytical methods panel data regression with the equation model as follows:

Description:

$$
\text { Yit }=\alpha+\beta 1 X \text { it }+\beta 2 X \text { it }+\varepsilon \text { it }
$$

Yit =financing income in the mudharabahthird month of the year

$\alpha \alpha \quad=$ constant

$\mathrm{X} 1$ itthird $\quad=\mathrm{BI}$ Rate the month of the year $\mathrm{t}$

$\mathrm{X} 2 \mathrm{itthird} \quad=$ The rate of profit sharing for the month of the year $\mathrm{t}$

$\beta 1 . \beta 2=$ Regression coefficient

$\varepsilon \quad=$ Error level (standard error)

\section{Discussion}

\footnotetext{
${ }^{3}$ http://www.bankmuamalat.co.id/profil-bank-muamalat
} 
Results of data processing or Estimates made using a computer program Eviews 7, using the panel data regression method shown in table 4 as follows:

\section{Table 4}

Regression Results ofFinancing Income Mudharabah

Dependent Variable: INCOME

Method: Panel Least Squares

Date: 05/18/17 Time: 11: 01

Sample: 160

Periods included: 12

Cross-sections included: 5

Total panel (balanced) observations: 60

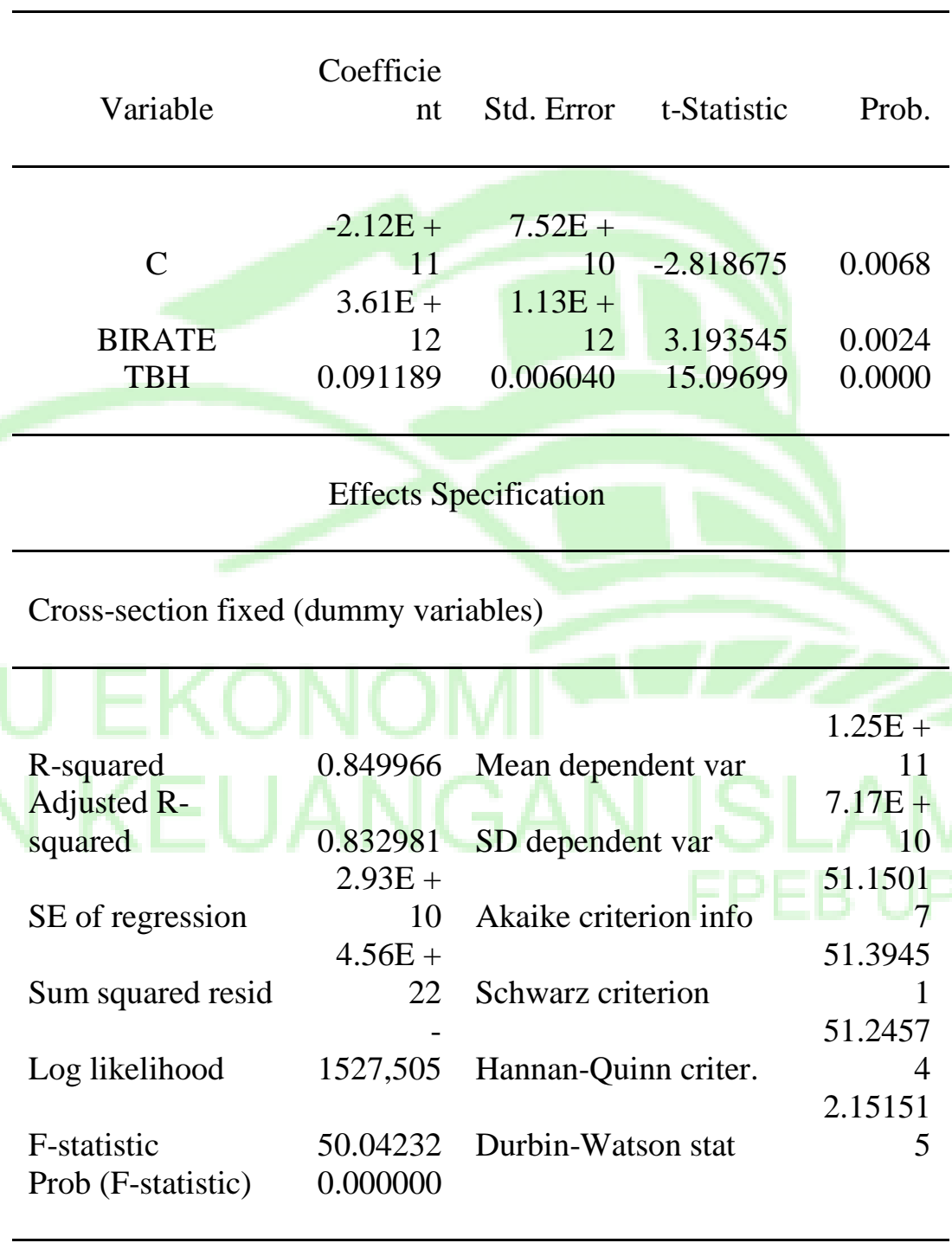

Data source: Processing Eviews 7

Based on the results of calculations performed using table 4 above, the multiple linear regression equation is obtained as follows:

$$
Y=-2.119+3,609 X_{1}+0,091 \text { XProfit }_{2}
$$


Description:

$\mathrm{Y}$

$\mathrm{X}_{1}$

= Financing Income Mudharabah

$\mathrm{X}_{2}$

$=\mathrm{BI}$ Rate

$=$ Sharing

Based on the regression equation, the influence of each independent variable on the dependent variable can be analyzed, namely:

constant $a$ of $-2,119$ states that if the value of the BI Rate $\left(\mathrm{X}_{1}\right)$ and TBH $\left(\mathrm{X}_{2}\right)$ is constant $(0)$, the variable value offinancing income mudharabah (Y)is $-2,119$.

The regression coefficient value $\mathrm{X}_{1}$ has a positive relationship of 3.609 for the BIvariable Rate, meaning that every $1 \%$ increase in the BI Rate, the income will increase by $3.609 \%$ in this case other factors are considered fixed.

Regression coefficient value $\mathrm{X}_{2}$ has a positive relationship of 0.091 for the variable TBH, which means that every $1 \%$ increase in the rate of profit sharing, then the income will increase by $0.091 \%$, in this case other factors are considered fixed.

a. Hypothesis 1

1) Test $\mathrm{T}$ test (Partial Test)

The $t$ test is used to test the hypothesis partially to show the effect of each independent variable individually on the dependent variable.

The results obtained from the statistical tests carried out can be seen in table 4.5 above with details as follows:

a) Effect of the BI Rate onFinancing Income Mudharabah

Based on the results in the table above the partial regression test ( $\mathrm{t}$ test) shows that the BIvariable regression coefficient is Rate 3.609 with t is 3,194 and prob. $0.0024<0.05$, Ho is rejected, meaning that the BI Rate affects thefinancing income mudharabah at PT Bank Muamalat Indonesia.

The results of this study are in accordance with the previous research conducted by Widianto \& Diyani in 2015 with the title of the study analyzing the influence of BI interest rates onfinancing mudharabah, with the results of his research showing a significant influence between BI interest rates onfinancing mudharabah.

Then by Fatmawati (2017), with the title of the study the influence of the BI Rate and the Bank's soundness on the level of profit sharing offinancing for the mudharabah Bank Syari'ah Mandiriperiod 2008-2015, the results of the research show that the BI Rate has a positive and significant effect on the level of profit sharing offinancing mudharabah.

b. Hypothesis 2

1) Test $\mathbf{T}$ test (Partial Test)

The $t$ test is used to test the hypothesis partially to show the effect of each independent variable individually on the dependent variable.

The results obtained from the statistical tests performed can be seen in table 4.5 above with the following details:

a) Effect of Profit Sharing Level onFinancing Income Mudharabah

Based on the results in the table above the variable profit-level regression coefficient (TBH) is 0.091 with t equal to 15.097 and prob. amounting to $0.0000<0.05$, Ho is rejected, meaning that the level of profit sharing affects thefinancing income mudharabah at PT Bank Muamalat Indonesia.

The results of this study are in accordance with the previous research conducted by Masduki (2012), with the title of the research that is the effect of the profit sharing ratio onfinancing volume mudharabah and musyarakah (case study at PT Bank Syari'ah Mandiri 2009-2011), the results of the research show the ratio forfinancing results Mudharabah have a positive and significant effect onfinancing volume mudharabah.

Then by Giannini (2013), in his research entitled factors influencingfinancing mudharabah in Sharia Commercial Banks in Indonesia, one of the factors influencingfinancing mudharabah is the rate of profit sharing, which proved to have a positive influence onfinancing mudharabah. 
The results are the same as those carried out by Iyonu (2015), his research entitled the influence of profit sharing onfinancing mudharabah (a case study of Sharia Commercial Banks in Indonesia), the results showed that the level of profit sharing affects the amount offinancing mudharabah.

Badruzaman (2009), with the title analysis of the influence of third party funds, profit sharing rates, bank Indonesia wadiah certificates on Syari'ah Bank financing in Indonesia (case study at PT Bank Syari'ah Mandiri), the results of this study indicate that for the short term and Long-term profit sharing rates show a significant effect on the amount offinancing mudharabah.

Andraeny (2011), his research entitled the analysis of the influence of third-party funds, profit sharing rates, and non-performing financing on the profit sharing-based financing volume in sharia banking in Indonesia, the results of his research showed that the level of profit sharing had a significant effect on the volume of profit-based financing in sharia banking in Indonesia.

\section{c. Hypothesis Test 3}

\section{1) Significant Test $F$ (test together)}

On simultaneous testing will be tested the influence of the two independent variables together on the dependent variable. Based on the results of the statistical test,table output themodel fixed effect above in table 4.5 output regressionshows the prob value. F statistic is $0,000<0,05(5 \%)$ so Ho is rejected, so it can be concluded that together the variable BI Rate and profit sharing rate (TBH) significantly influence thefinancing variable mudharabah in PT Bank Muamalat Indonesia.

\section{2) test Adjusted $\mathbf{R}^{2}$ (Coefficient of Determination) Determination}

Coefficient (KD) is used to see how much the independent variable (X) has an impact on the dependent variable (Y) expressed in percentages. Based on thetable output model fixed effect in table 4.5 above it can be seen that the value of Adjusted R-square is 0.832981 that means that together the variable BI Rate and profit sharing rate have a contribution to explain thefinancing income mudharabah of $83.3 \%$, while the remaining $16.7 \%(100 \%-83.3 \%)$ is explained by other variables not examined or not included in this research model.

\section{A. Explanation of Research Results The}

\section{Effect of the BI Rate onFinancing Income Mudharabah}

Based on the results of this study it is known that the BI Rate has a positive and significant effect onfinancing income mudharabah, the results of this study are consistent with the previous research conducted by Widianto \& Diyani in 2015 with the title of the study analyzing the influence of BI interest rates onfinancing mudharabah, with the results of his research showing a significant influence between BI interest rates onfinancing mudharabah. Then by Fatmawati (2017), with the title of the study the influence of the BI Rate and the Bank's soundness on the level of profit sharing offinancing for the mudharabah Bank Syari'ah Mandiriperiod 2008-2015, the results of the research show that the BI Rate has a positive and significant effect on the level of profit sharing offinancing mudharabah.

As we know that the BI Rate is the reference interest rate issued by BI which is ultimately followed by rising deposit rates, loans, deposits with conventional banks, therefore if interest rates rise then people will tend to save their money in conventional banks compared to Syari'ah Bank due to the high deposit interest rate is in accordance with the classical economic outlook, but it is different for people who want to do financing or loans they will think and compare high loan interest rates and switch to Syari'ah Bank to finance financing The Shari'ah Bank does not set interest but with the principle of profit sharing, therefore the income of the Sharia Bank financing will increase.

\section{Influence of Profit Sharing Rate (TBH) onFinancing Income Mudharabah}

After testing that the profit sharing rate has a positive and significant influence onfinancing income mudharabah, this result is in accordance with the previous research conducted by Masduki (2012), with the title of the research namely the effect of financing sharing ratio onfinancing volumes mudharabah and musyarakah (case study at PT Bank Syari'ah Mandiri 2009-2011), the results of his research show that the profit sharing ratio offinancing mudharabah has a positive and significant effect onfinancing volume mudharabah. 
Then by Giannini (2013), in his research entitled factors influencingfinancing mudharabah in Sharia Commercial Banks in Indonesia, one of the factors influencingfinancing mudharabah is the rate of profit sharing, which proved to have a positive influence onfinancing mudharabah.

The results are the same as those carried out by Iyonu (2015), his research entitled the influence of profit sharing onfinancing mudharabah (a case study of Sharia Commercial Banks in Indonesia), the results showed that the level of profit sharing affects the amount offinancing mudharabah.

The results are the same as those carried out by Iyonu (2015), his research entitled the influence of profit sharing onfinancing mudharabah (a case study of Sharia Commercial Banks in Indonesia), the results showed that the level of profit sharing affects the amount offinancing mudharabah.

Badruzaman (2009), with the title analysis of the influence of third party funds, profit sharing rates, Bank Indonesia wadiah certificates on Syari'ah Bank financing in Indonesia (case study at PT Bank Syari'ah Mandiri), the results of this study indicate that for the short term and Long-term profit sharing rates show a significant effect on the amount offinancing mudharabah.

Andraeny (2011), his research entitled the analysis of the influence of third party funds, profit sharing rates, and non-performing financing on the volume of profit sharing based financing in sharia banking in Indonesia, the results of his research showed that the level of profit sharing had a significant effect on the volume of financing based on results in sharia banking in Indonesia.

Profit sharing is one of the characteristics that distinguishes between Syari'ah Banks and Conventional Banks. This profit sharing system is a profit sharing after reaching an agreement between the customer and the Bank, usually in the form of a percentage by conducting profit sharing or by dividing income.

Therefore this profit sharing system is one of the contributors to Syari'ah Bank income, the higher the profit sharing rate offered by the Shari'ah Bank, the higher the financing income obtained because there can still be many Indonesian customers comparing the rate of profit sharing with interest in Conventional Banks but not a few customers who make financing or deposits at the Shari'ah Bank based on religious beliefs.

\section{Influence of the BI Rate and Profit Sharing Rate onFinancing Income Mudharabah}

Based on the results of the F statistical test shows the statistical F F value is $0.000<0.05(5 \%)$, so it can be concluded that together the BI Rate and profit sharing rate (TBH) ) have a significant effect on the variablefinancing income mudharabah. Then based on the analysis of coefficient of determination can be seen that the value of Adjusted $R$-square is 0.832981 This means that the variable BI Rate and profit sharing rate together have a contribution to explain theincome mudharabah of $83.3 \%$, while the remaining $16.7 \%(100 \%-83.3 \%)$ is explained by other variables not examined or not included. in this research model.

As explained above, the BI Rate and profit sharing rate affectfinancing income mudharabah both individually and jointly, although the Shari'ah Bank does not use the interest system, but when the BI Rate is raised it will have a positive impact on the financing of the Shari'ah Bank because the loan interest will increase even though the deposit interest rate also rises in Conventional Banks, so for prospective customers who will make loans / financing will prefer the Syari'ah Bank because they do not use the interest system but profit sharing.

Then for the level of profit sharing itself it is clear that when the Syari'ah Bank raises the level of profit sharing offered to customers will make the amount of financing increase by looking at the conditions on interest on loans / financing at Conventional Banks is experiencing an increase, therefore financing income at the Bank Shari'ah will also increase especiallyfinancing mudharabah, and it is evident from the results of testing the data $\mathrm{R}^{2}$ shows that the BIvariable Rate and the profit sharing rate have an influence of $83.3 \%$, the figure is high enough to influence thefinancing income variable mudharabah while the remaining $16.7 \%$ which could be influenced by other variables not examined in this study. 


\section{Concluding Remarks \\ 5.1 Conclusions}

Based on the results of the research and discussion discussed above, some conclusions can be drawn as The following:

1. The independent variable BI Rate has a positive and significant influence on the income offinancing mudharabah. Evidenced by the regression coefficient value of the BIvariable Rate of 3.609 with $\mathrm{t}$ of 3.194 and prob. $0.0024<0.05$. This means that when the BI Rate increases, the proportion offinancing income mudharabah will increase.

2. Independent variables of profit sharing have a positive and significant effect onfinancing income mudharabah. This is evidenced by the regression coefficient (TBH) of 0.091 with $\mathrm{t}$ of 15.097 and prob. amounting to $0.0000<0.05$. Meaning The higher the level of profit sharing offered and implemented by Syari'ah Bank Indonesia especially Bank Muamalat Indonesia will increase the amount offinancing mudharabah then followed by an increase infinancing income mudharabah at Bank Muamalat Indonesia.

3. Based on the joint testing of the independent BIvariable Rate and the rate of profit sharing has an influence and significant on the dependent variable offinancing income mudharabah, this is evidenced by the prob value. F statistic is $0,000<0,05(5 \%)$ and with the results of Rtesting $2303,3 \%$ while the remaining $16,7 \%(100 \%-83,3 \%)$ is explained by other variables not examined or not included in the model this research.

\subsection{Suggestions}

1. for Banks

For the Bank to pay attention to theBI Rate depresseddevelopment has a positive influence onfinancing income mudharabah, so when the BI Rate is increased, thefinancing income mudharabah will increase, this occurs because prospective customers who want to do financing / loans / credit switch to Syari'ah Bank because the interest on loans / credit at Conventional Banks has increased.

Then to pay attention to the level of profit sharing because it has a positive and significant influence onfinancing income mudharabah, the higher the level of profit sharing offered, the more people will make financing and ultimately increase thefinancing income mudharabah, but still have to be careful in distributing funds due to their benefits. not sure.

2. For Academics

For further researchers to extend the study period and use more variables that affectfinancing income mudharabah, such as increasing the number of banks studied so that they can compare between other Syari'ah Banks, so that they can provide more accurate and good research results. This is, the limitations in this study in terms of periods of time that are not too long and the research variables are few.

\section{REFERENCES}

Aini, Nur. (2017). Bisnis Bank Syariah 2017 Berpeluang Terus Melonjak Ini Alasannya. Diambildarihttp://www.republika.co.id/berita/ekonomi/syariahekonomi/17/01/18/ojy976382bisnis-bank-syariah-2017-berpeluang-terus-melonjak-ini-alasannya. Diakses Tanggal 8 Juni 2017.

Andraeny, Dita. (2011). Analisis Pengaruh Dana Pihak Ketiga, Tingkat Bagi Hasil, Dan Non Performing Financing Terhadap Volume Pembiayaan Berbasis Bagi Hasil Pada Perbankan Syari'ah Di Indonesia. Simposium nasional akuntansi ke XIV. Aceh. 047. 1-28.

Antonio, Muhammad Syafi'i. (2011). Bank Syaiah: Dari Teori ke Praktik. Jakarta: Gema Insani.

Al-Arif, M. Nur Rianto. (2012). Lembaga Keuangan Syari'ah. Bandung: Pustaka Setia.

Badruzaman, Najahi. (2009). Analisi Pengaruh Dana Pihak Ketiga, Tingkat Bagi Hasil, dan Sertifikat Wadiah Bank Indonesia Terhadap Pembiayaan Bank Syariah Indonesia. Skripsi: Tidak Diterbitkan.

Baltagi, Bagi. (2005). Econometric Analysis of Panel Data. Third Edition. Jhon Wiley \& Sons. 
Bank Indonesia (2017). BI Rate. Diambil dari http://www.bi.go.id/id/moneter/biRate/penjelasan/Contents/Default.aspx. Diakses tanggal 20 maret 2017.

Bank Muamalat Indonesia (2017). Profil Bank Muamalat. Diambil dari http://www.bankmuamalat.co.id/profil-bank-muamalat. Diakses tanggal 20 maret 2017.

Fatmawati, Nur Lailatul (2017). Pengaruh BI Rate dan Tingkat Kesehatan Bank terhadap Tingkat Bagi Hasil Pembiayaan Mudharabah Bank Syari'ah Mandiri periode 2008-2015. Skripsi: Tidak Diterbitkan.

Ghozali, Imam. (2013). Aplikasi analisis multivariate dengan Program SPSS. Semarang: Badan Penerbit Universitas Diponegoro.

Giannini, Nur Gilang (2013). Faktor yang mempengaruhi pembiayaan mudharabah pada bank umum syari'ah di Indonesia. Accounting Analysis Journal, 2 (1), (2252-6765), 97-103.

Gujarati, Damodar. (2004). Dasar-Dasar Ekonometrika. Jakarta : Erlangga.

Hidayat, Anwar. (2017). Tutorial Regresi Data Panel dengan Eviews. Diambil dari https://www.statistikian.com/2017/04/tutorial-regresi-data-panel-dengan-eviews.html. Diakses pada tanggal 27 Mei 2017.

Hidayat, Anwar. (2017). Tutorial Uji Asumsi Klasik dengan Eviews. Diambil dari https://www.statistikian.com/2017/02/tutorial-uji-asumsi-klasik-eviews.html. Diakses pada tanggal 27 Mei 2017.

Hak, Nurul. (2011). Ekonomi Islam Hukum Bisnis Syari'ah. Yogyakarta: Sukses Offset.

Huda, Nurul \& Heykal, Mohamad. (2010). Lembaga Keuangan Islam: Tinjauan Teoretis dan Praktis. Jakarta: Kencana.

Iyonu, Mentari Ariesta. (2015). Pengaruh Tingkat Bagi Hasil Terhadap Pembiayaan Mudharabah. 14597-14548-1.

Karim, Adiwarman. (2004). Bank Islam Analisis Fiqh \& Keuangan. Jakarta : PT. Raja Grafindo Persada.

Karl, E. Case \& Fair, Rai C. (2001). Prinsip-Prinsip Ekonomi Makro. Jakarta: Prenhalindo.

Kasmir. (2000). Manajemen Perbankan. Jakarta : PT Raja Grafindo Persada.

Khalwaty, Tajul. (2000). Inflasi dan Solusinya. Jakarta : PT Gramedia Pustaka.

Mankiw, N Gregory. (2003). Teori Makro Ekonomi Edisi kelima. Terjemahan. Jakarta : Erlangga.

Masduki. (2012). Pengaruh nisbah bagi hasil pembiayaan terhadap volume pembiayaan mudharabah dan musyarakah. Semarang: Tidak Diterbitkan.

Muhamad. (2002). Manajemen Bank Syariah. Yogyakarta : UPP AMPYKPN.

Nachrowi, N. Djalal \& Hardius, Usman. (2006). Pendekatan Populer dan Praktis Ekonometrika untuk Analisis Ekonomi dan Keuangan. Jakarta : LPFE Universiatas Indonesia.

Nasution, Mustafa Edwin. (2010). Pengenalan Eksklusif Ekonomi Islam. Jakarta: Prenada Media Group.

Nopirin. (2000). Ekonomi Moneter. Buku II. Edisi 1. Yogyakarta : BPFE UGM

Palupi, Isnaini Fajrin Nadia. (2015). Analisis Pengaruh Dana Pihak Ketiga, Tingkat Bagi Hasil, Non Performing Financing dan Modal Sendiri terhadap Volume Pembiayaan Berbasis Bagi Hasil pada Perbankan Syariah Di Indonesia Studi Kasus Bank Muamalat Indonesia. Skripsi : Tidak Diterbitkan.

Rohmana, Yana. (2010). Ekonometrika Teori dan Aplikasi dengan Eviews. Bandung: Laboratorium Pendidikan Ekonomi dan Koperasi.

Rostanti, Qommarria \& Zuraya, Nidia. (2013). BI Rate Naik, Bank Syari'ah Hati-Hati Salurkan Pembiayaan. Diambil dari http://www.republika.co.id/BI Rate Naik, Bank Syari'ah Hati-Hati Salurkan Pembiayaan_Republika Online.htm. Diakses tanggal 26 juni 2016.

Rozalinda. (2015). Ekonomi Islam Teori dan Aplikasinya dalam Aktivitas Ekonomi. Jakarta: PT. RajaGrafindo Persada.

Setiawan \& Kusrini, Dwi Endah. (2010). Ekonometrika. Yogyakarta: CV. Andi Offset.

Simorangkir, Iskandar. (2014). Pengantar Kebanksentralan Teori dan Praktik di Indonesia. Jakarta: PT. RajaGrafindo Persada.

Sjahdeini, Sutan Remy. (2015). Perbankan Syari'ah Produk-Produk dan Aspek-Aspek Hukumnya. Jakarta: Prenada Media Group.

Sudarwanto, Barno. (2013). Perbankan Syari'ah Pasca kenaikan BI Rate. Diambil dari http://Muhammad/Subhan.htm. Diakses tanggal 26/10/2016. 
Sugiyono. (2014). Metode Penelitian Kuantitatif Kualitatif dan Kombinasi (Mixed Method). Bandung: Alfabeta.

Sujarweni, V.Wiratna. (2015). Metodologi Penelitian Bisnis Ekonomi. Yogyakarta: Pustaka Baru Press. Sukirno, Sadono. (2000). Ekonomi Pembangunan Proses Masalah dan Dasar Kebiajakan Pembangunan. Jakarta : UI-Press.

Sunariyah. (2011). Pengantar Pengetahuan Pasar Modal. Yogyakarta : UPP STIM YKPN.

Susanto, Burhanuddin. (2008). Hukum Perbankan Syariah Indonesia. Yogyakarta : UII Press Yogyakarta.

Sutanto, Herry \& Umam, Khaerul. (2013). Manajemen Pemasaran Bank Syari'ah. Bandung: Pustaka Setia.

Wahab. (2014). Analisis Pengaruh Fdr, Npf, Tingkat Bagi Hasil, Kualitas Jasa dan Atribut Produk Islam Terhadap Tingkat Pembiayaan Mudharabah Pada Bank Umum Syari'ah di Semarang. Economica, Vol 5 edisi 2 - (456345), 107-136.

Widarjono, Agus. (2007). Ekonometrika : Teori dan Aplikasi untuk Ekonomi dan Bisnis edisi kedua. Yogyakarta : Ekonisia FE Universitas Islam Indonesia.

Widiyanto, Edo \& Diyani, Lucia Ari. (2015). Analisis Pengaruh Suku Bunga BI Terhadap Pembiayaan Mudharabah. Kalbi Socio Jurnal Bisnis dan Komunikasi, 2 (1), (2356-4385), 98-108.

Wiroso. (2005). Penghimpunan Dana dan Distribusi Hasil Usaha Bank Syariah. Jakarta: PT Grasindo.

Yulianto, Agus. (2017). Bank Syariah Mau Maju Pesat Kaafah Jawabannya. Diambil dari http://www.republika.co.id/berita/jurnalisme-warga/wacana/17/04/18/oojpmv396-banksyariah-mau-maju-pesat-kaafah-jawabannya. Diakses Tanggal 8 juni 2017. 